\title{
Local Ecological Knowledge on Forest Clearing: A Case Study of Parak and Rimbo Practices in Simancuang Community, Indonesia
}

\author{
Ferdinal Asmin ${ }^{1,2}$, Dudung Darusman ${ }^{2}$, Iin Ichwandi², Didik Suharjito ${ }^{2}$ \\ ${ }^{1}$ West Sumatra Forestry Agency, Indonesia \\ ${ }^{2}$ Bogor Agricultural University, Indonesia
}

DOI: http://dx.doi.org/10.15294/komunitas.v8i2.5856

Received : 30 April 2016; Accepted: 27 September 2016; Published: September 2016

\begin{abstract}
Local communities are frequently judged as the main driver of forest degradation and deforestation because of the weak recognition to local ecological knowledge (LEK) or traditional ecological knowledge (TEK). We assessed that it is important to elaborate the attributes of LEK and TEK as a way to describe why and how the local community clears the forest, as well as its relation to local practices, named parak and rimbo. The research uses case study method to describe the local practices in Simancuang community, Alam Pauh Duo Village, South Solok District, West Sumatra Province. The research conducted unstructured interviews, observations, and documents selection which were analyzed through categorization and codification as well as complemented with history analysis, spatial analysis, and related document analysis. The results showed that Simancuang community knowledge can describe the attributes of LEK and TEK as a unified whole of local knowledge for sustaining their livelihoods. Therefore, the forest clearing by Simancuang people is one of the livelihoods strategies, but they were not the main driver of forest degradation and deforestation in South Solok District.
\end{abstract}

Keywords: attributes of LEK and TEK; livelihoods; forest degradation; deforestation

\section{INTRODUCTION}

Forest resources utilization by local and indigenous communities for sustaining their livelihoods always generates a discourse in related to forest degradation and deforestation issues. Some scholars assessed that there is no convincing evidence of forest degradation and deforestation caused by economic activities of local communities (Angelsen and Kaimowitz 1999; Ellis and Porter-Bolland 2008; Bax et al. 2016). Otherwise, some scholars convinced that forest management by local communities can minimize forest degradation and deforestation (Ellis and Porter-Bolland 2008). Even, when forest resources conservation became a government strategy to overcome forest degradation and deforestation caused by local communities, the strategy often threatens community livelihoods (Marie et al. 2009). Therefore, we should ensure local community interests in related to forest degradation and deforestation issues (Agrawal et al. 2011) and avoid the understanding trapped in the myths as described by Kull (2000).

Scientific discourses on forest degradation and deforestation still continue because there are two different views about the driver of forest degradation and deforestation. According to the first view, local community that depended on agriculture and forestry activities was judged as a driver of the increasing forest degradation and deforestation (Mulyanto and Jaya 2004; Kissinger et al. 2012). This argument is supported by the facts that subsistence/local agriculture practices have contributed $33 \%$ of deforestation (Hosonuma et al. 2012; Weatherley- 
Singh and Gupta 2015) and low community education also causes the increasing deforestation rate (Salahodjaev 2016). The second view believed that the government policies give more significant forest degradation and deforestation, especially for agriculture (Galinato and Galinato 2016). Then, forest degradation and deforestation issues have become a part of development and power discourses (Nygren 2000) since the colonial era (Jarosz 1993) until today with sustainable development and carbon trade issues (van der Hoff et al. 2015).

We assess that discourses on the driver of forest degradation and deforestation have degraded the understanding about the relationship between local communities and forest resources and may occur in 3 causes. The first cause is the weaknesses of socio-ecological understanding (Chalmers and Fabricius 2007), even though we need broadly contexts to understand the land use changes (Sheil and Wunder 2002), including socio-ecological and socio-economic aspects. The second cause is the weaknesses of legal recognition to local and indigenous communities (Kaimowitz 2003). The third cause is the weaknesses of recognition to the local ecological knowledge (LEK) and traditional ecological knowledge (TEK), even though LEK and TEK are set of knowledge based on experiences that showed the community capability to overcome the environmental changes (Gómez-Baggethun et al. 2013). Many scholars have been interested to study the first and the second causes, but the third cause has not been elaborated comprehensively. This research elaborated the relationship between local communities and forest resources by using the concept of LEK and TEK to explain why and how the local communities clear the forest land. Although LEK differs from TEK in the context of cultural transmission, TEK is also characterized by using LEK in natural resources management (Berkes et al. 200o). LEK and TEK are internalized and shared to next generation (Lauer and Aswani 2009) and they are the accumulation of community knowledge about their relation to others and their environments (Charnley et al. 2008). Some challenges in using this concept were identified (Houde 2007; Bart 2006), but we introduce the attributes of LEK and TEK from Menzies and Butler (2006) as a way to explain LEK and TEK systematically and holistically. The attributes of LEK and TEK were studied by understanding the activities of Simancuang community (i.e. Simancuang Sub-Village and Karang Hitam Simancuang Sub-Village) in Alam Pauh Duo Village, South Solok District, West Sumatra Province, Indonesia. Elaborating the attributes was related to the existence of parak as one of agroforestry practices and rimbo as production, protection, or reserved forest for the community.

\section{METHODS}

Collecting data and information was conducted from October 2015 until December 2015 through unstructured interviews with local people who know the process of forest clearing and the establishment of new subvillage (jorong). Interviewed people as local experts are research subjects and knowledge holder about forest clearing and its relation to parak and rimbo. Local experts were considered based on their position in local government and customary system, their activities in related to parak and rimbo, and their understanding of local culture and history. Besides that, interviews were conducted with many informants who get involved in the local empowerment of Simancuang community. The selection of informants is very important to ensure reliability (Davis and Wagner 2003).

The interviews were analyzed by categorization and codification in accordance with the attributes of LEK and TEK, namely long-term and cumulative, dynamic, historical, local, holistic, embedded, as well as moral and spiritual. Each attribute was elaborated comprehensively and can complete each other as defined in Table 1 . The discussion was enriched with history analysis, spatial analysis, and related documents analysis. Focus of our discussion is the implication of LEK and TEK in related to sustain the community livelihoods and to argue the myths of the driver of forest degradation and deforestation. 
Table 1. Operational definitions of LEK and TEK attributes

\begin{tabular}{ll}
\hline Attributes & Operational Definitions \\
\hline $\begin{array}{l}\text { Long-term and cu- } \\
\text { mulative }\end{array}$ & $\begin{array}{l}\text { Initiation time of forest clearing and its relations to parak and rim- } \\
\text { bo, as well as how the community understanding over generations }\end{array}$ \\
Dynamic & $\begin{array}{l}\text { The patterns of cultivation, harvesting, and technology in forest } \\
\text { clearing and their relations to parak and rimbo, according to social, } \\
\text { economic, and ecological activities }\end{array}$ \\
Historic & $\begin{array}{l}\text { Adaptation capability to environmental changes caused by forest } \\
\text { clearing and their relations to parak and rimbo, both socio-econom- } \\
\text { ic and socio-ecological }\end{array}$ \\
Local & $\begin{array}{l}\text { Local specificity of forest clearing, parak, and rimbo in terms of } \\
\text { property rights, management rights, and the existence of traditions }\end{array}$ \\
Holistic & $\begin{array}{l}\text { The relationship between parak and rimbo and other resources after } \\
\text { forest clearing that shows the community capability to manage their } \\
\text { natural resources in context of sustainability }\end{array}$ \\
Embedded & $\begin{array}{l}\text { Internalization of parak and rimbo after forest clearing and the de- } \\
\text { velopment of cultural traditions from generation to generation }\end{array}$ \\
Moral and spiritual & $\begin{array}{l}\text { Reciprocal relations and spiritual values among local people in for- } \\
\text { est clearing and the practices of parak and rimbo based on their be- } \\
\text { liefs }\end{array}$
\end{tabular}

\section{RESULT AND DISCUSSION}

\section{Study Area and Its History}

Simancuang Sub-Village and Karang Hitam Simancuang Sub-Village are the new settlement of Simancuang community included in the administrative area of Alam Pauh Duo Village, Pauh Duo Sub-District, South Solok District. Simancuang community is part of Minangkabau ethnic in West Sumatera Province. They call sub-village as jorong and village as nagari, as well as jorong is part of nagari as the lowest local government (Kahn 1984, Fatimah 2008). Head of jorong is called as wali jorong and head of nagari is called as wali nagari. Actually, nagari is not only administrative area but also the autonomous socio-economic area for Minangkabau community (Oki 1977). Both subvillages, previously, were one sub-village, namely Simancuang. The name was taken from the first person who cleared the forest in 1974. Formerly, Simancuang people cleared the forest land for looking a new agricultural land (especially rice field) and initiated by a farmer group named Durian Tigo Capang with 14 members. Until the end of the 1980s, people started making the house in Simancuang which becomes the pioneer of the new settlement, although they were only getting recognition as a sub-village (jorong) from the government since 2002 . In 2014, Simancuang Sub-Village was separated into 2 sub-villages, namely Simancuang Sub-Village and Karang Hitam Simancuang Sub-Village, as well as consists of 8 clans, namely Sikumbang, Malayu, Panai, Durian, Bariang, Kampai, Kuti Anyia, and Koto Kaciak.

Our study area is included in Batanghari watershed which is upstream of Batanghari River and flows across the middle of Sumatera Island. This area also near from the forest ecosystem of Kerinci Seblat National Park. According to the Indonesian forestry law (see Figure 1 ), the area is 1,450 ha and divided into the protected forest $57 \%$ and other uses area $43 \%$. Based on land cover in 2013, land uses consist of secondary forest $45 \%$, dry agricultural land $21 \%$, mixed agricultural land $20 \%$, rice field $12 \%$, and shrubs $2 \%$. Slopes of the area are very steep and steep, $22 \%$ and $16 \%$ respectively, while flat and slope slightly are $22 \%$ and $23 \%$ res- 
pectively, and the rest is rather steep.

Based on the statistic of Alam Pauh Duo Village at 2015, Simancuang populations are 948 people with 224 households and only $12 \%$ of Alam Pauh Duo village populations. Almost all of Simancuang people are the farmer with rice field as main family livelihoods and parak as alternative family livelihoods. This area is also known as one of the organic agricultural practices in West Sumatra because Simancuang farmers are not using chemical fertilizers in rice production. Although rice harvesting was only 3 times in 2 years, Simancuang people can suffice their demands, even they can sell it to the market. Currently, they are trying to increase the rice production 2 times in one year by adopting the organic agricultural system that is introduced by the government. Meanwhile, they have been cultivating cash crops, annual crops, and trees in their dry land (parak). Parak can produce any com- modities, such as cardamom, ginger, coffee, cinnamon, cacao, durian, and timber.

Sustainability of their livelihoods has been getting a large attention by Simancuang communities as they proved by the struggle to get an administrative recognition and rights of state forest management in term of village forest (hutan nagari). They succeed to get a forest management right about 650 ha of state forest in 2012 and became one of village forest pioneers in West Sumatera as written by Asmin (2015). Their successful struggle gave impacts to increase infrastructure services, such as improvement of access roads that were formerly passable on foot or two-wheeled vehicle and improvement of electrical access by establishing a micro hydro power plant and connecting to state electrical power plant. Institutionally, Simancuang community was also contributed to increase the development of Alam Pauh Duo Village and this village was awarded by

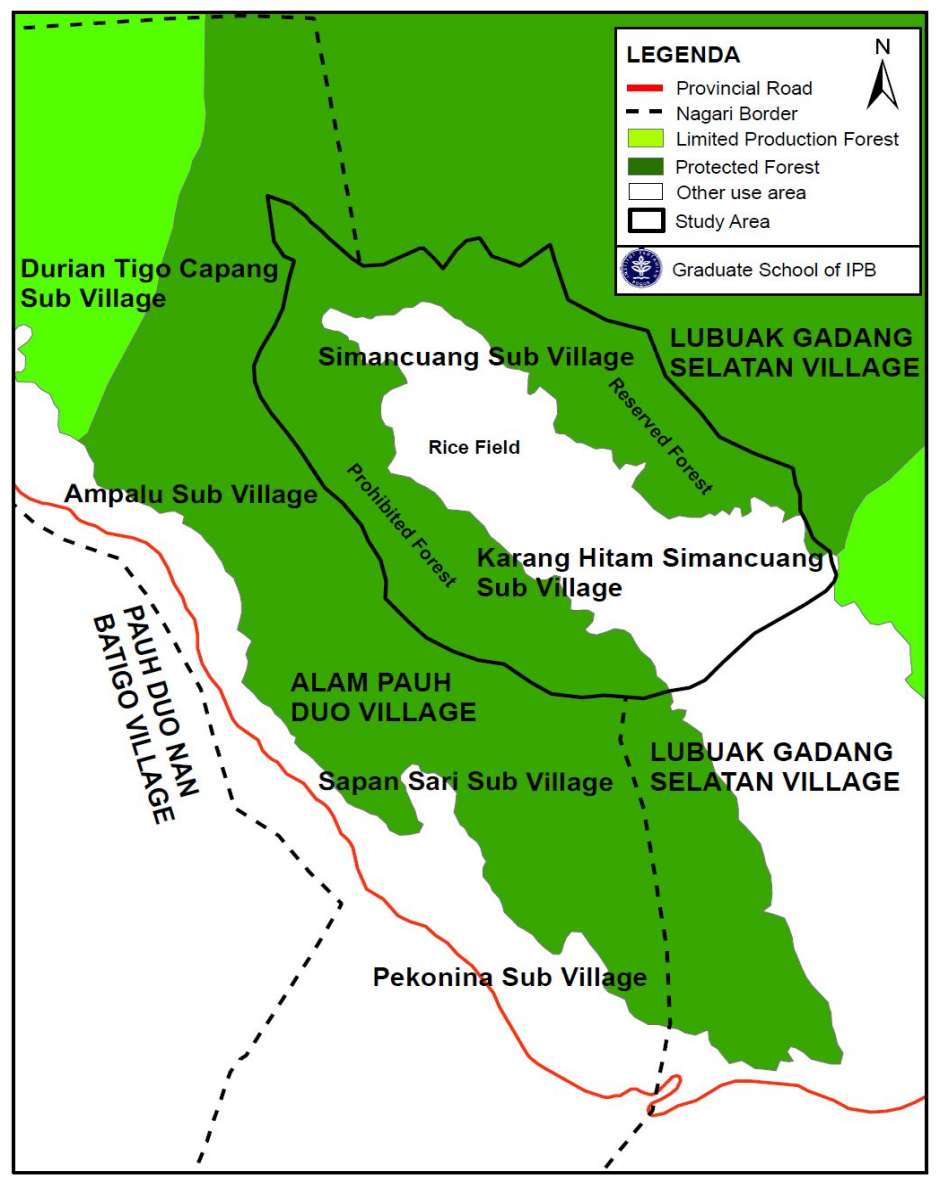

Figure 1. The study area of Simancuang community 
the government as environmentally friendly village and forestry village at national and provincial level.

\section{LEK/TEK on Forest Resources Manage- ment}

\section{Attributes of long-term and cumulative}

Minangkabau communities have been known as agricultural communities. In the beginning of 20 th century, almost $90 \%$ family income was generated from agricultural lands (Oki 1984), such as rice fields, dry land for annual crops, and parak. Dutch East Indies Government also judged West Sumatra as the important food production sources since the early 19th century, especially rice (Oki 1977). However, West Sumatera actually has limited land for agriculture because some lands are hilly and valley land, as well as forested land. These conditions caused many people moving to another area to seek a feasible agricultural land (Abdullah 2010). Based on hereditary experiences, people have been known that slope land is suitable for parak and flat land is suitable for rice field (nan lereang dijadikan parak nan bancah dijadikan sawah). Therefore, since the colonial era, they cultivated paddy on relatively flat land and cash crops on slope land such as cinnamon, coffee, and rubber (Otsuka 2000).

The areas along provincial road, especially in the Sub-District of Koto Parik Gadang Diateh, Sungai Pagu, Pauh Duo, and Sangir, have many relatively flat lands with supporting by Batanghari River for irrigation, so all lands have been becoming rice field. The road was established before late 17th century (Colombijn 2005) and connecting Padang City in West Sumatra Province and Kerinci District in Jambi Province since 1921 (Asnan 2002). The presence of road increased agricultural activities, both rice field and parak cultivation, because the increase of agriculture product trade. Rice field produced plentiful rice and parak produced cash crops that were sold to Padang and Kerinci. Currently, almost 90\% of rice production in South Solok District is still coming from this area (Badan Pusat Statistik Ka- bupaten Solok Selatan 2015). Parak is still becoming the sources of alternative family income and known as a type of agroforestry practices (Otsuka 2000; Murniati et al. 2001)

The knowledge about rice cultivation on relatively flat land and agroforestry practices on slope land were known by Simancuang community from generation to generation. The judgment of land suitability for rice field was based on soil type, land slope, and proximity to water sources. Rice field has the most important values as inheritance goods for Minangkabau communities (Oki 1984; Hadler 2010). For seasonal crops land (ladang) and parak, they choose lands with the slope under 30\% and cultivate the mixed annual and perennial crops. As their original place, formerly, they cultivated coffee and cinnamon that were mixed with bayur (Pterospermum javanicum) and surian (Toona sureni). In line with market demands, they also cultivated cacao and rubber since the last 2010s. To sustain water supply for rice field, they appointed the forested land in the West (they are called it Bukit Panjang) as forbidden or prohibited forest (rimbo larangan) and in the East as reserved or alternative forest (hutan cadangan). Currently, Bukit Panjang has gotten approval from the government as village forest (hutan nagari).

\section{Attributes of dynamic}

Simancuang area was formerly covered by dense forest. They claimed this area as heritage land (ulayat) of Sungai Pagu Kingdom. Furthermore, almost all people in Simancuang that cleared the forest came from some villages in Sungai Pagu territories. They proved the genealogical-territory natures of Minangkabau communities (von BendaBeckmann and von Benda-Beckmann 2001; Warman and Andora 2014). In 1974, the forest clearing was conducted in a group named Durian Tigo Capang that was consisting of 14 members. Each member contributed 5,00o Rupiah and got an area of 50 x 50 meters along Simancuang River. Since the early 1980 os, many people came to Simancuang area and got the approval of group leader to clear other forested lands for rice field, but they were only approved to clear the lands 
until the foothills. The group members had the rule of the game to get a land. They limited rice field ownership only area of $50 \mathrm{x}$ 50 meters until the foothills. They also ruled transfer of rights among members and to other persons. The lands which were not cultivated in 6 months must be returned to group and transfer of rights must be approved by the group leader. These rules adopted the system of land property applied in $\mathrm{Mi}-$ nangkabau communities (Oki 1977).

Forested lands that have been cleared for rice field are main sources of livelihoods for Simancuang community. As other Minangkabau communities, they always combined their livelihoods by utilizing wetlands and dry lands (Otsuka 2000; Murniati et al. 2001). Minangkabau farmers were courageous to take a risk in the cultivation of their lands, even though they were subsistent farmers (Oki 1984, p.173). The agroforestry practices in dry lands (parak) are one of $\mathrm{Si}$ mancuang community strategies to meet family needs by utilizing the lands in hillsides. They cultivated coffee, cinnamon, and rubber in hillside lands that were mixed with seasonal crops. The replacing of cultivated crops depended on the prices and market demands. For example, as the price of cinnamon was decreased in the last 200os, they began to cultivate rubber because the price of rubber was increased.

But, not all forested lands were cleared by Simancuang people. They knew that forested lands in the upper lands with steep slope must be maintained for ensuring water supply of settlement and rice fields, as well as protecting them from landslides and floods. Forest clearing in the West (Bukit Panjang area) was limited and then this area was appointed as rimbo larangan. They have only approved the forest land activities in the East that were agreed as rimbo cadangan. The allocation of forested lands is similar to the pattern of spatial allocation that was usually found in other Minangkabau communities as written by Nursidah et al. (2012) and Hamzah et al. (2015).

\section{Attributes of historical}

Simancuang community has understood the importance of protecting forest as they want to clear the forested lands for rice field. Their agreement to protect the forest area in the West was a form of sustaining their rice fields and settlement. They have experienced flood and landslide disasters while they inhabited in the original place. The areas in the Western of South Solok District were known as hilly regions and the upper catchment area of Batanghari River that are vulnerable to floods and landslides.

Rice field and parak in Simancuang began to cultivate intensively since 1987 . The land clearing was done by slashing and burning the trees. This practice was usually done by Minangkabau farmers (Colfer et al. 1988; Otsuka 200o), but this should not be identified as shifting cultivation because they were directly cultivating seasonal and perennial crops (Otsuka et al. 2001). For parak, they were only cutting down the non-commercial trees and maintaining the commercial trees such as bayur, surian, and durian. The commercial trees are for protecting the lands from landslide and the noncommercial trees are replaced with cash crops such as coffee, cinnamon, and rubber.

Flood and landslide have once happened in Simancuang. In 1990, the landslide occurred in Bukit Panjang that caused the damage to 0.25 ha rice fields. The land was later abandoned because Simancuang people fear that disaster will occur in next time. But, the landslide has never been repeated. Since 2010, the land was cultivated for parak and ladang. Meanwhile, the flash flood never occurred in Simancuang. In the peak of the rains, Simancuang River ever overflows only caused the puddles in some rice fields around Simancuang mosque. The puddles were not causing a serious damage to rice fields. To anticipate the puddles, they always dig the soil sediment in the river. In socioecological perspectives, we assessed that $\mathrm{Si}-$ mancuang community has the adaptive capability in the contexts of transformability, learning, and innovation development and we called it as resilience (Folke 2006).

The adaptive capability of Simancuang community in the perspectives of socio-economic was also happened reactively, 
concurrently or anticipatively, spontaneously or planned as written by Smit et al. (200o) and Pelling and High (2006). The reactive adaptation was shown by replacing the cash crops in parak in line with the dynamic of market demand. For sustaining their rice fields and parak as sources of livelihoods, they have also encouraged the legal recognition of Bukit Panjang area (forested lands in the West) into village forest that consists of forbidden forest (rimbo larangan) and cultivated forest (parak). For the forested lands in the East, they claimed them as the reserved forest that is the next cultivated lands for the next generations. These actions are the form of their adaptation to anticipate the population growth and community needs.

\section{Attributes of local}

The knowledge of Simancuang people about parak and rimbo, principally, are generally same as other Minangkabau communities. Although this area was recognized as sub-village (jorong) since 2002, the natural resources management still applied the tradition and knowledge of Minangkabau communities. We assessed it in 2 circumstances. First, property rights consist of common and private ownerships. Parak and rimbo are judged as common resources inherited by their ancestors since Sungai Pagu Kingdom era. That circumstance may be considered as von Benda-Beckmann (1979) said that the jungle belongs to King (nagari leader), the cultivable but yet uncultivated area belongs to clan leader (panghulu/niniak mamak), and the area under cultivation belongs to clan members (anak kamanakan). The lands which were genealogically inherited are called as material heritages (harato pusako) that consist of the lands from the ancestors in relatively long time (harato pusako tinggi) and the lands from family properties in recently time (harato pusako randah). For Simancuang people, harato pusako tinggi are parak and rimbo, while harato pusako randah are rice fields and ladang. Harato pusako tinggi are governed by clan leaders (niniak mamak), while harato pusako randah are only governed by family members that are generally based on Islamic law.
Second, Simancuang people also agreed to appoint the Bukit Panjang area as rimbo larangan and forested lands in the East as rimbo cadangan. Rimbo larangan are generally appointed in forested lands with slope $30 \%$ up. The terms of rimbo larangan are also known by other Minangkabau communities in some villages like studied by Martial et al. (2012), Nursidah et al. (2012), and Hamzah et al. (2015). Rimbo larangan was recognized by the government in 2012 after they proposed it become village forest that was agreed by Simancuang people since 2010. This village forest is one of the pioneers of village forest movement in West Sumatra. Meanwhile, rimbo cadangan was cultivated for parak and ladang because it is generally having slope under 30\%. The forest clearing in rimbo cadangan can only be done by jorong members based on the agreement of clan leaders. The agreement considers land slope, type of crops, and the origin of the family. If the lands were not cultivated in a certain time, the property of the lands must be returned to clan leaders.

\section{Attributes of holistic}

Forest clearing by Simancuang people was aimed to seek new rice fields because the limitations of the cultivable land for rice field (around Muaro Labuah, Sungai Pagu Sub-District). Although the density of $\mathrm{Mu}-$ aro Labuah populations has increased about 4-fold, but the rice field ownership among farmers has decreased 4-fold from 1923 to 2014 (Kahn 1984; Badan Pusat Statistisk Kabupaten Solok Selatan 2015). This condition may encourage the farmers to clear the new forested land that can be cultivated. And then, newly cultivated lands were inhabited by other family and clan members until this area become a new sub-village.

The community knowledge on forest clearing and in making a new sub-village is related to the territorial concept of Minangkabau communities (Navis 2015). There are 8 prerequisites of one village, namely having meeting hall and mosque (babalai bamusajik), having clans and customary village (basuku banagari), having sub-village and housing (bakorong bakampuang), having 
security and information system (bahuma babendang), having clear boundaries (balabuah batapian), having rice field and dry land farm (basawah baladang), having yard and large field (bahalaman bapemedanan), and having cemetery (bapandam bapusaro). These prerequisites were applied by Simancuang people, and for allocating spaces in their area, they considered the physical natures of the land as described in Figure 2.

How they clear the forest was illustrated in Figure 2. Selecting rice field based on land slope and water supply. Relatively flat land and near to water supply are usually for rice field and settlement, meanwhile ot- her lands can become rimbo larangan and rimbo cadangan. Forested lands with slope $30 \%$ up will become rimbo larangan, but potential forested lands for parak and ladang will become rimbo cadangan. Uncultivated lands will be let as forested land (primary or secondary forest). The failures to cultivate the lands may be caused by social, economic and ecological constraints, such as employment, financial crisis, and natural disasters. If these constraints occurred, they will abandon and let it become abandoned land which can be forested land in the future.

Minangkabau farmers assessed the existence of rice field as an important entity

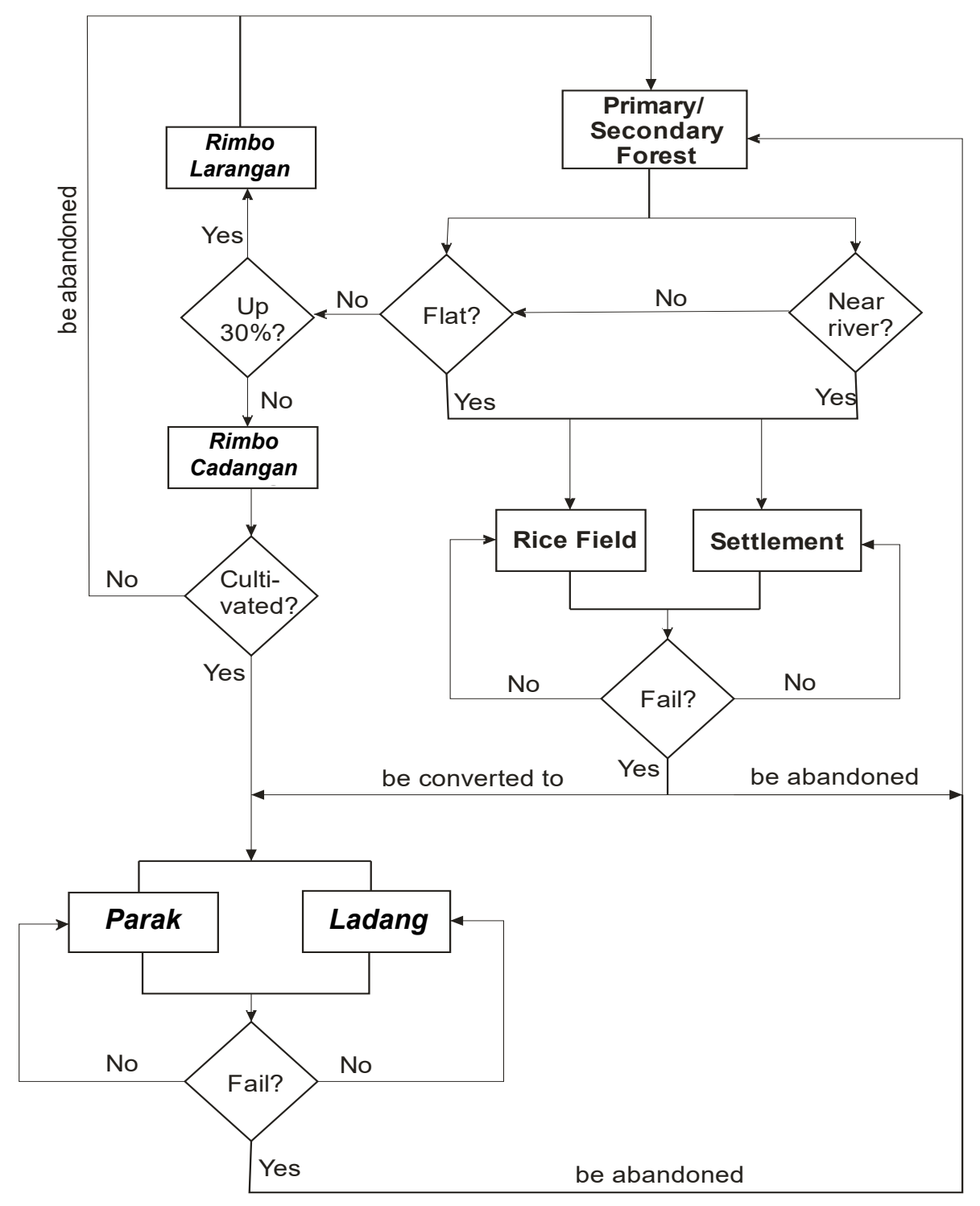

Figure 2. Community knowledge on forest clearing and spatial allocation 
to sustain their livelihoods (Oki 1984; Otsuka 2000; Hadler 2010). Dry land agriculture, especially parak and ladang, for commercial objectives was developed since colonial era (Otsuka 200o). Furthermore, the forest clearing for developing new territory and new cultivable land has been implemented by Simancuang communities according to their experience based knowledge. Their knowledge has experienced a cycle of explicit and tacit knowledge as described by Nonaka et al. (2006) and Nonaka and Toyama (2007). It proved that there are the processes of knowledge internalization and we assessed it in 2 ways.

The first way is the Simancuang community cleared the forested land in a group by forming new farmers group named $\mathrm{Du}^{-}$ rian Tigo Capang and made some rules, such as land suitability criteria, land allocation and transfer of rights, and membership mechanism. After became a sub-village, they were also applying the structure of Minangkabau community by selecting their representatives according to clan or sub-clan who have the role in maintaining the community welfare and governing the customary rule. The roles are similar to the roles of panghulu or niniak mamak (Junus 1984). Then, their representatives encouraged the protection of some forested lands as rimbo larangan and rimbo cadangan. All Simancuang people have been prohibited from cultivating rimbo larangan, meanwhile, rimbo cadangan can be cultivated for parak and ladang after they got the approval of their representatives. Actions in the group are a strong of Simancuang people as when they propose the Bukit Panjang area as village forest to the government.

The second way is the Simancuang people applied some traditions like other Minangkabau traditions. One of the traditions is mandarahi kapalo banda (maintain catchment area). This tradition is the customary party before cultivating rice field by slaughtering a buffalo and distributing its meat to all Simancuang people. This tradition is also applied by other people in Pauh Duo and Sungai Pagu Sub-District. David and Ploeger (2014) also studied this tradi- tion as one of the forms of water resources management in Padang Laweh Malalo Village, Tanah Datar District. This district has been believed as the original place (luhak) of all Minangkabau communities. The tradition of mandarahi kapalo banda in Simancuang was started since 1984 by inviting village and district government leaders to get higher attention in developing and conserving their area. This tradition also showed that all people should manage their water resources to ensure water availability for rice fields and resident houses. Maintaining the water resources for ensuring its availability to local people needs according to local wisdom is also applied by other local people like Osing people, Papua people, Sunda people, and Dayak people (Sumarmi 2015).

\section{Attributes of moral and spiritual}

All Simancuang people are the followers of Islam that have been introduced since the 16th century. Acculturation of Islamic law and Minangkabau customary law has occurred since the middle of 19th century (Hadler 2010) by implementing the concept of customary law based on Islamic law and Islamic law based on Al-Qur'an (adaik basandi syarak, syarak basandi kitabullah). Values system of Minangkabau people has known the understanding to four things (paham nan ampek) that are manifestation of alam takambang jadi guru (learning from nature). The understandings are often depicted in the form of rhymes (Gani 2009). The values can be inherited by their philosophy (cupak usali) and making an agreement (cupak buatan) (Navis 2015). These values have been recognized by Simancuang people.

The implementation of values can be described by a set of words that shows the understanding of Simancuang people about the relationship between human and environment. The similar way is also used by other communities like Kanekes community in West Java (Indrawardana 2012). The words (kato) will contain teachings, counsel, and law (Navis 2015). As settlement, rice field, ladang, parak and rimbo are the important entities of sub-village spatial, they apply the philosophy of baadaik balimbago bacupak 
bagantang (have customary system, institution, values, and measures) and tahu jo diri sendiri, tahu jo urang lain, tahu jo alam, dan tahu jo Allah (know himself, other people, the nature, and God). As rimbo is judged as forbidden and reserved forest, and parak is judged as production forest, they believe that their ancestors have inherited a truth of "dari dalil kato Allah, dari hadis kato nabi, dari kato pusako, dari mufakaik” (from God, Prophet, hereditary, and agreement). As mandarahi kapalo banda is believed as a tradition to sustain the sources of their livelihoods, they realize the traditional teachings of raso jo pareso (feeling and checking). As they govern the communal rights and ban tree felling in prohibited forest, they give power to the local leader for manuruik alua nan luruih, manampuah jalan nan pasa, mamaliharo anak jo kamanakan, dan mamaliharo harato pusako (according to the truth, maintaining solidarity, maintaining family members, and maintaining hereditary).

\section{LEK and TEK, livelihoods, and the myths of forest degradation and defor- estation}

LEK/TEK on forest clearing should be considered as a livelihood strategy. Livelihood is a process to get a living included means and ends of capability, equity, and sustainability (Chambers and Conway 1992; Chambers 1995). We discussed the facts of LEK and TEK in the context of livelihood to argue the myths of forest degradation and deforestation. The myths were generated by 3 arguments, namely population growth, poverty, and slash and burn agriculture (Kull 2000).

Population growth may cause the increasing of forested lands for agriculture. But, we should not think that local farmers will clear forested land carelessly. For Simancuang people as part of Minangkabau communities, rice field is the main source of family livelihood and considered as harato pusako (Oki 1984; Hadler 2010). Forested lands usually can be cleared for rice field, but only on relatively flat lands. The slope lands cultivated as parak and other lands will be protected as rimbo. Furthermore, although the number of rice field farmers increased about 6-fold (Kahn 1984) in South Solok District, the number of rice field only increased about 2-fold (Badan Pusat Statistik Kabupaten Solok Selatan 2015) from 1923 to 2014 (see Table 2). Rice field farmers knew that existence of parak and rimbo is important for protecting their rice field. These facts showed the capability, equity, and sustainability of farmers to sustain their livelihoods based on LEK and TEK as described previously.

Table 2. Facts of the Number of Rice Field Farmers in South Solok District

\begin{tabular}{lrr}
\hline \multicolumn{1}{c}{ Data } & 1923 & 2014 \\
\hline Number of population & 51,646 & 159,901 \\
Number of rice field & 4,483 & 29,536 \\
farmers & & \\
Rice field area (ha) & 5,760 & 9,490
\end{tabular}

Source: Kahn (1984) and Badan Pusat Statistik Kabupaten Solok Selatan (2015)

The condition of farmers after Indonesia independence in 1945 have oppressed because uncertainties of tenure rights and increasing economic gap (Kahn 1980). Since the 1970s, Indonesia Government claimed many forested lands as the state forest and gave management rights to corporate. About 30,000 ha of forest area in South Solok District were given to private logging company in 1978 and some of the forested lands were given to private plantation company in the 1980s. These circumstances have increased the vulnerability of farmers in tenure security, decreased farmer power in the decision making of cultivation, and humiliated farmer rights in sustaining their livelihoods. Simancuang people experienced this condition before and after clearing the state forest for rice field. They never got government aids in establishing rice field, parak, ladang, and settlement because they practiced slash and burn agriculture which was always identified as shifting cultivation. Actually, they always cultivated the lands directly after clearing and are different from shifting cultivator (Otsuka et al. 2001). Recognition of their existence was only gotten after Indonesian reformation movement since 1998 by 
appointing their area into one sub-village of Alam Pauh Duo Village in 2002.

Our findings show that about $52 \%$ of natural resources in South Solok District were managed by private companies for mining, plantation and forestry activities, and only about $12 \%$ were managed by local farmers (see Table 3) (Badan Pusat Statistik Kabupaten Solok Selatan 2015). The rest are still covered by primary and secondary forest. These data suggested that private companies are the most potential driver of forest degradation and deforestation than local farmers.

Table 3. The Rights of Natural Resources Management in South Solok District

\begin{tabular}{lllll}
$\begin{array}{c}\text { Type of } \\
\text { Activities }\end{array}$ & $\begin{array}{c}\text { For } \\
\text { Local } \\
\text { Farmers } \\
\text { (ha) }\end{array}$ & $\begin{array}{c}\text { For } \\
\text { Private } \\
\text { (ha) }\end{array}$ & $\%$ \\
\hline Mining & - & - & 38521 & 11.51 \\
Plantation & 25176 & 7.52 & 94495 & 28.24 \\
Forestry & 16937 & 5.06 & 41486 & 12.40 \\
\hline
\end{tabular}

Source: Badan Pusat Statistik Kabupaten Solok Selatan (2015)

Table 3 shows that the legal right of farmers to manage the natural resources management from the government is lower than private. According to this data, farmers were not the main driver of forest degradation and deforestation in South Solok District. So, we cannot judge farmers as forest degrader because we cannot ensure the equity of right to manage the natural resources to them.

Elaborating the attributes of LEK and TEK in Simancuang community should give us the comprehensive and holistical understanding of forest clearing by local people. We judged that forest clearing was initiated to sustain their livelihoods. Means and ends based on LEK and TEK show the capability, equality, and sustainability of forest resources management. But, we understood that the community capability is not only related to knowledge predominance as human capital, but also collective action as a flow of social capital. LEK and TEK should contribute to the accumulation of social capital in a community. This is a challenge in next research.

\section{CONCLUSION}

Community knowledge on natural resources management, both LEK and TEK, can show the community capability to sustain and maintain their natural resources. We elaborated the attributes of LEK and TEK in studying local practices of forest clearing. The attributes of LEK and TEK gave us an understanding of how and why Simancuang people clear the forest and maintain the existence of parak and rimbo. Each attribute cannot be separated and become a unified whole of describing community knowledge on forest resources management. We suggest that next research on LEK and TEK should elaborate its attributes for getting a systematic explanation about community knowledge.

We conclude that the forest clearing based on LEK and TEK by Simancuang people is a way of sustaining their livelihoods. They cleared forest for rice field as the main source of livelihood. The existence of rice field is related to parak and rimbo as the alternative source of livelihood. They always consider the integration among sources of livelihood for production and protection. The facts of LEK and TEK, as well as the history of local farmers in South Solok District, give us adequate arguments to refuse the myths which judged local farmers as the main driver of forest degradation and deforestation. Nevertheless, we understood that knowledge predominance should be developed into collective action as a flow of social capital. Furthermore, the next research should be conducted to explain the elements of social capital which are related to forest resources management.

\section{ACKNOWLEDGEMENT}

We thank Indonesia Endowment Fund for Education, Ministry of Finance, for supporting this research. We also thank Simancuang people, especially customary leaders, village leaders, and local informants, for helping us to provide data and information, as well as the non-governmental organizati- 
on of KKI Warsi and West Sumatra Forestry Agency.

\section{REFERENCES}

Abdullah, T., 2010. "Pengantar", in Jeffrey Hadler (ed) Sengketa Tiada Putus: Matriarkat, Reformisme Agama, dan Kolonialisme di Minangkabau, Freedom Institute, Jakarta, pp.i-xxxviii.

Agrawal, A., Nepstad, D., \& Chhatre, A., 2011. Reducing Emissions from Deforestation and Forest Degradation. Annu. Rev. Environ. Resour, 36, pp.373-96.

Angelsen, A., \& Kaimowitz, D., 1999. Rethinking the Causes of Deforestation: Lessons from Economic Models. The World Bank Research Observer, 14(1), pp.73-98.

Asmin, F., 2015. Pengelolaan Hutan Nagari di Sumatera Barat: Studi Kasus Areal Kelola Hutan Nagari di Jorong Simancuang Provinsi Sumatera Barat. Prosiding Seminar Nasional FMIPA UT Tahun 2015 Jakarta, Universitas Terbuka, pp.89-112.

Asnan, G., 2002. Transportation on the West Coast of Sumatra in the Nineteenth Century. Bijdragen tot de Taal-, Land-en Volkenkunde, 158(4), pp.727-741.

Badan Pusat Statistik Kabupaten Solok Selatan. 2015. Solok Selatan dalam Angka Tahun 2015. Badan Pusat Statistik Kabupaten Solok Selatan, Padang Aro.

Bart, D., 2006. Integrating Local Ecological Knowledge and Manipulative Experiments to Find the Causes of Environmental Change. Front Ecol Environ, 4(10), pp.541-546.

Bax, V., Francesconi, W., \& Quintero, M., 2016. Spatial Modeling of Deforestation Processes in the Central Peruvian Amazon. Journal for Nature Conservation, 29, pp.79-88.

Berkes, F., Colding, J., \& Folke, C., 20oo. Rediscovery of Traditional Ecological Knowledge as Adaptive Management. Ecological Applications, 10(5), pp.1251-1262.

Chalmers, N., \& Fabricius, C., 2007. Expert and Generalist Local Knowledge about Land-Cover Change on South Africa's Wild Coast: Can Local Ecological Knowledge Add Value to Science? Ecology and Society, 12(1), pp.10-24.

Chambers, R., 1995. Poverty and Livelihoods: Whose Reality Counts? Environment and Urbanization, 7(1), pp.173-204.

Chambers, R. and Gordon R.C., 1992. Sustainable Rural Livelihoods: Practical Concepts for the 21st Century. Institute of Development Studies, University of Sussex, Brighton.

Charnley, S.A., Fischer, P., \& Jones, E.T., 20o8. Traditional and Local Ecological Knowledge about Forest Biodiversity in the Pacific Northwest. US Department of Agriculture, Portland.

Colfer, C.J. P., Gill, D.W., \& Agus, F., 1988. An Indigenous Agricultural Model from West Sumatra: A Source of Scientific Insight. Agricultural Sys- tems, 26, pp.191-209.

Colombijn, F., 2005. A Moving History of Middle Sumatra, 1600-1870. Modern Asian Studies, 39(1), pp.1-38.

Davis, A., \& Wagner, J.R., 2003. Who Knows? On the Importance of Identifying "Experts" when Researching Local Ecological Knowledge. $\mathrm{Hu}$ man Ecology, 31(3), pp.463-489.

Ellis, E.A., \& Porter-Bolland, L., 2008. Is Community-Based Forest Management More Effective than Protected Areas? A Comparison of Land Use/Land Cover Change in Two Neighboring Study Areas of the Central Yucatan Peninsula, Mexico. Forest Ecology and Management, 256, pp.1971-1983.

Fatimah, S., 2008. Mencermati Perubahan Sosial Masyarakat Minangkabau melalui Novel Tamu Karya Wisran Hadi. Humaniora, 20(3), pp.278-285.

Folke, C., 2006. Resilience: The Emergence of a Perspective for Social-Ecological Systems Analyses. Global Environmental Change, 16, pp.253267.

Galinato, G,I., \& Galinato, S.P., 2016. The Effects of Government Spending on Deforestation due to Agricultural Land Expansion and $\mathrm{CO}^{2} \mathrm{Re}-$ lated Emissions. Ecological Economics, 122, pp.43-53.

Gani, E., 2009. Kajian terhadap Landasan Filosofi Pantun Minangkabau. Jurnal Bahasa dan Seni, 10(1), pp.1-10.

Gómez-Baggethun, E., Corbera, E., \& Reyes-García, V., 2013. Traditional Ecological Knowledge and Global Environmental Change: Research Findings and Policy Implications. Ecology and Society, 18(4), pp.72-79.

Hadler, J., 2010. Sengketa Tiada Putus: Matriarkat, Reformisme Agama, dan Kolonialisme di Minangkabau. Freedom Institute, Jakarta.

Hamzah, Suharjito, D., \& Istomo. 2015. Efektifitas Kelembagaan Lokal dalam Pengelolaan Sumber Daya Hutan pada Masyarakat Nagari Simanau, Kabupaten Solok. Risalah Kebijakan Pertanian dan Lingkungan, 2(2), pp.116-127.

Hosonuma, N., et al., 2012. An Assessment of Deforestation and Forest Degradation Drivers in Developing Countries. Environ. Res. Lett., 7, pp.1-12.

Houde, N., 2007. The Six Faces of Traditional Ecological Knowledge: Challenges and Opportunities for Canadian Co-Management Arrangements. Ecology and Society, 12(2), pp.34-40.

Indrawardana, I., 2012. Kearifan Lokal Adat Masyarakat Sunda dalam Hubungan dengan Lingkungan Alam. Komunitas, 4(1), pp.1-8.

Jarosz, L., 1993. Defining and Explaining Tropical Deforestation: Shifting Cultivation and Population Growth in Colonial Madagascar (18961940). Economic Geography, 69(4), pp.366379 .

Junus, U., 1984. Kaba dan Sistem Sosial Minangkabau: Suatu Problematika Sosiologi Sastra. PN 
Balai Pustaka, Jakarta.

Kahn, J.S., 1980. Minangkabau Social Formations: Indonesia Peasants and the World Economy. Cambridge University Press, New York.

Kahn, J.S., 1984. Peasant Political Conciousness in West Sumatra: A Reanalysis of the Communist Uprising of 1927. Senri Ethnological Studies, 13, pp.293-325.

Kaimowitz, D., 2003. Forest Law Enforcement and Rural Livelihoods. International Forestry Review, 5(3), pp.199-210.

Kissinger, G., Herold, M., \& de Sy, V., 2012. Drivers of Deforestation and Forest Degradation: A Synthesis Report for REDD+ Policymakers. Lexeme Consulting, Vancouver.

Kull, C.A., 200o. Deforestation, Erosion, and Fire: Degradation Myths in the Environmental History of Madagascar. Environment and History, 6(4), pp.421-450.

Lauer, M., \& Aswani, S., 2009. Indigenous Ecological Knowledge as Situated Practices: Understanding Fishers' Knowledge in the Western Solomon Islands. American Anthropologist, 111(3), pp.317-329.

Marie, C.N., et al., 2009. Taking into Account Local Practices and Indigenous Knowledge in an Emergency Conservation Context in Madagascar. Biodivers Conserv., 18, pp.2759-2777.

Martial, T., Effendi, N. \& Martius, E., 2012. Land and tree tenure rights on agro forestry (parak) system at communal land in West Sumatra, Indonesia. Journal of Agricultural Extension and Rural Development, 4(19), pp.486-494.

Menzies, C.R., \& Butler, C., 2006. "Understanding Ecological Knowledge", in Charles R. Menzies (ed) Traditional Ecological Knowledge and Natural Resource Management, University of Nebraska, London, pp.1-17.

Mulyanto, L., \& Jaya, I.N.S., 2004. Analisis Spasial Degradasi Hutan dan Deforestasi: Studi Kasus di PT. Duta Maju Timber, Sumatera Barat. Jurnal Manajemen Hutan Tropika, X(1), pp.29-42.

Garrity, D.P. and Gintings, A.N., 2001. The contribution of agroforestry systems to reducing farmers' dependence on the resources of adjacent national parks: a case study from Sumatra, Indonesia. Agroforestry Systems, 52(3), pp.171184 ..

Navis, A.A., 2015. Alam Terkembang Jadi Guru: Adat dan Kebudayaan Minangkabau. Penerbit Grafika Jaya Sumbar, Padang.

Nonaka, I., Von Krogh, G. \& Voelpel, S., 2006. Organizational knowledge creation theory: Evolutionary paths and future advances. Organization studies, 27(8), pp.1179-1208.

Nonaka, I., \& Toyama, R., 2007. "Why Do Firms Differ? The Theory of the Knowledge-Creating Firm", in Kazuo Ichijo and Ikujiro Nonaka (ed) Knowledge Creation and Management: New Challenges for Managers, Oxford University Press, Oxford, pp.13-31.
Nursidah, N.B., Darusman, D., Rusdiana, O. and Rasyid, Y., 2012. Pengembangan institusi untuk membangun aksi kolektif lokal dalam pengelolaan hutan kawasan lindung SWPDAS Arau, Sumatera barat. Jurnal Manajemen Hutan Tropika, 18(1), pp.18-30.

Nygren, A., 200o. Development Discourses and Peasant-Forest Relations: Natural Resource Utilization as Social Process. Development and Change, 31, pp.11-34.

Oki, A., 1977. Social Change in the West Sumatran Village: 1908-1945. Australian National University, Canberra.

Oki, A., 1984. The Dynamics of Subsistence Economy in West Sumatra. Senri Ethnological Studies, 13, pp.267-291.

Otsuka, M., 200o. Challenges to Land Use Intensification under Commercialization of Local Farming Systems: A Case from West Sumatra, Indonesia. TROPICS, 9(4), pp.309-322.

Otsuka , K., et al., 2001. Evolution of Land Tenure Institutions and Development of Agroforestry: Evidence from Customary Land Areas of Sumatra. Agricultural Economics, 25, pp.85-101.

Pelling, M., \& High, C., 2005. Understanding Adaptation: What Can Social Capital Offer Assessments of Adaptive Capacity? Global Environmental Change, 15, pp.308-319.

Salahodjaev, R., 2016. Intelligence and Deforestation: International Data." Forest Policy and Economics, 63, pp.20-27.

Sheil, D., \& Wunder, S., 2002. The Value of Tropical Forest to Local Communities: Complications, Caveats, and Cautions. Conservation Ecology, 6(2), pp.9-24.

Smit, B., et al., 200o. An Anatomy of Adaptation to Climate Change and Variability. Climatic Change, 45, pp.223-251.

Sumarmi, S., 2015. Local Wisdom of Osing People in Conserving Water Resources. Jurnal Komunitas, 7(1), pp.43-51.

Weatherley-Singh, J., \& Gupta, A., 2015. Drivers of Deforestation and REDD+ Benefit-Sharing: A Meta-Analysis of the (Missing) Link. Environmental Science $\mathcal{E}$ Policy, 54, pp.97-105.

van der Hoff, R., Rajão, R., Leroy, P. and Boezeman, D., 2015. The parallel materialization of REDD+ implementation discourses in Brazil. Forest Policy and Economics, 55, pp.37-45.

von Benda-Beckmann, F., 1979. Property in Social Continuity: Continuity and Change in the Maintenance of Property Relationships through Time in Minangkabau, West Sumatera. Springer-Science+Business Media, B.V.

von Benda-Beckmann, F., \& von Benda-Beckmann. , K., 2001. Recreating the Nagari: Decentralization in West Sumatra. Working Paper No.31. Max Planck Institute for Social Anthropology.

Warman, K., \& Andora, H., 2014. Pola Hubungan Hukum dalam Pemanfaatan Tanah Ulayat di Sumatera Barat. Mimbar Hukum, 26(3), pp.366-381. 